\title{
SPATIAL DEPENDENCE INDEX FOR CUBIC, PENTASPHERICAL AND WAVE SEMIVARIOGRAM MODELS
}

Índice de dependência espacial para os modelos de semivariogramas cúbico, pentaesférico e wave

Edemar Appel Neto ${ }^{1}$ - ORCID: 0000-0003-1698-7535

Ismael Canabarro Barbosa²;

Enio Júnior Seidel ${ }^{2}$ - ORCID: 0000-0002-9656-0699

Marcelo Silva de Oliveira ${ }^{1}$

${ }^{1}$ Universidade Federal de Lavras (UFLA), Departamento de Estatística, Lavras-MG, Brasil.

E-mail: nettoappel@hotmail.com; marcelo.oliveira@dex.ufla.br

${ }^{2}$ Universidade Federal de Santa Maria (UFSM), Departamento de Estatística, Santa Maria-RS, Brasil.

E-mail: ismaelcanabarro@hotmail.com; enioseidel@gmail.com

Received in June, $20^{\text {th }}, 2017$.

Accepted in January $16^{\text {th }}, 2018$.

\section{Abstract:}

This study aims to propose a spatial dependence index (and its classification), from the concept of spatial correlation areas, for the Cubic, Pentaspherical and Wave models. The index, called Spatial Dependence Index (SDI), covers the following parameters: the range $(a)$, the nugget effect $\left(C_{0}\right)$ and the contribution $\left(C_{1}\right)$, beyond considering the maximum distance $(M D)$ between sampled points and the model factor $(M F)$. The proposed index, unlike the most used in the literature, considers the influence of the range parameter to describe the spatial dependence, highlighting the importance of this formulation. The spatial dependence classification, based on the observed asymmetric behavior in the SDI, was performed considering categorizations from the median and the $3 r d$ quartile of the index. We obtain the spatial dependence classification in terms of weak, moderate, and strong, just as it is usually described in literature.

Keywords: Model factor; Geostatistics; Spatial variability; Descriptive measures.

\section{Resumo:}

Este estudo tem como objetivo propor um índice de dependência espacial (e sua classificação), a partir do conceito de áreas de correlação espacial, para os modelos Cúbico, Pentaesférico e Wave. O índice, denominado Índice de Dependência Espacial (IDE), abrange os seguintes parâmetros: o alcance $(a)$, o efeito pepita $\left(C_{0}\right)$ e contribuição $\left(C_{1}\right)$, além de considerar a distância máxima entre pontos amostrados $(M D)$ e o fator modelo $(F M)$. O índice proposto, ao contrário do mais utilizado na literatura, considera a influência do parâmetro alcance para descrever a dependência espacial, destacando a importância desta formulação. A classificação de dependência espacial, construída

How to cite this article: Neto,E,A, et al. Spatial dependence index for cubic, pentaspherical and wave semivariogram models. Bulletin of Geodetic Sciences, Vol. 24, issue 1, 142-151, Jan-Mar, 2018. 
com base no comportamento assimétrico observado no IDE, foi realizada considerando categorizações da mediana e do 3 o quartil do índice. Obtemos a classificação de dependência espacial em termos de fraca, moderada e forte, tal como é normalmente descrito na literatura.

Palavras-chave: Fator do modelo; Geoestatística; Variabilidade espacial; Medidas descritivas.

\section{Introduction}

In Earth Sciences is common to perform mapping of the spatial distribution of attributes (Yamamoto et al., 2012). In this sense, Geostatistics is the most used methodology, since it provides optimal techniques for mapping the behavior of geo-referenced variables. These techniques are conducted through the interpolation of information from data obtained in locations sampled and modeled in a semivariogram (Faraco et al., 2008), producing a spatial mapping and understanding of the spatial distribution of the phenomenon values.

Olea (2006) presents the most commonly used semivariogram mathematical models: Spherical, Exponential, Gaussian, Pentaspherical, Cubic, Wave (models with sill) and Power Model (model without sill). Each of these mathematical models is defined by a mathematical expression and each expression is specified by real numbers called parameters.

From the model parameters it is possible to construct spatial dependence indexes that allow to summarize the spatial dependence degree and complement the semivariogram interpretation. The relative nugget effect (NE) is the most used index and it considers the relationship between the nugget effect and the sill (Trangmar et al., 1985; Cambardella et al., 1994). Another measure that can be used is the spatial dependence degree (SPD) (Biondi et al., 1994), obtained by the relationship between the contribution and the sill. Both of these indexes, widely diffused in the Agricultural Sciences and Soil Sciences, classify the spatial dependence into weak, moderate or strong, based on the proposed classification by Cambardella et al. (1994).

Another index that can be mentioned is the spatial dependence index (SDI) of the Spherical, Exponential and Gaussian semivariogram models, which considers the relationship between the contribution, the sill, the range, the distance of the sampling grid and the model factor (MF) (specific elements of each model) (Seidel, Oliveira, 2014a). This index holds a spatial dependence classification proposed by Seidel, Oliveira (2016) and it is categorized as weak, moderate or strong spatial dependence. Recently, Barbosa et al. (2017) constructed indexes and respective classifications for the evaluation of the spatial dependence for the power semivariogram model (model without sill). According to Barbosa et al. (2017), the proposed indexes are analogous to the SPD and SDI.

Spatial dependence measures are useful to make classifications and comparisons among different spatial dependence scenarios (different spatial phenomena) (Biondi et al., 1994) without the necessity to take the whole semivariogram. In addition, as an index, they can be used to evaluate the quality of model fit to the semivariogram (Ávila, et al., 2010; Pazini, et al., 2015; Oldoni, Bassoi, 2016; Buttow et al., 2017) and, in consequence, to indicate whether the kriging interpolation will result in good quality maps. 
Even though the Cubic, Pentaspherical and Wave models have potential applicability in the Environmental Sciences, Geosciences, Soil Sciences and others, there is not a spatial dependence index that considers their specifications. Thus, this article aims to propose the construction of the SDI index, and its respective classification, based on Seidel, Oliveira (2014a; 2016), for these three semivariogram models, so that all models presented in Olea (2006) (considered as the most commonly used) can have their SDI index.

\section{Methodology}

The mathematical expressions of the Cubic, Pentaspherical and Wave semivariogram models are given by (Olea, 2006), respectively:

$$
\begin{aligned}
& \gamma(h)=\left\{\begin{array}{l}
C_{0}+C_{1}\left[7\left(\frac{h}{a}\right)^{2}-\frac{35}{4}\left(\frac{h}{a}\right)^{3}+\frac{7}{2}\left(\frac{h}{a}\right)^{5}-\frac{3}{4}\left(\frac{h}{a}\right)^{7}\right], h<a \\
C_{0}+C_{1}
\end{array}, h \geq a\right. \\
& \gamma(h)=\left\{\begin{array}{l}
C_{0}+C_{1}\left[\frac{15}{8}\left(\frac{h}{a}\right)-\frac{5}{4}\left(\frac{h}{a}\right)^{3}+\frac{3}{8}\left(\frac{h}{a}\right)^{5}\right], h<a \\
C_{0}+C_{1}
\end{array}, h \geq a\right. \\
& \gamma(h)=\left\{\begin{array}{l}
C_{0}+C_{1}\left(\begin{array}{c}
1-\frac{\sin \left(\pi \frac{h}{a}\right)}{h} \\
a
\end{array}\right)
\end{array}\right.
\end{aligned}
$$

where $C_{0}$ is the nugget effect and $C_{1}$ is the contribution (or partial sill), $\mathrm{C}=C_{0}+C_{1}$ is the sill, $a$ is the range parameter, $h$ is the distance between points and $\gamma(h)$ is the theoretical model of the semivariogram.

These models are used to estimate the spatial dependence structure of phenomena that have second order stationarity, which leads to the existence of a sill. When there is a sill, the modelling can be done using the semivariogram or the correlogram. The latter leads to a more adequate algebric or numerical analysis. From this finding, we can express the correlogram model as:

$$
\rho(h)=1-\frac{\gamma(h)}{C}
$$

where $\gamma(h)$ is the theoretical model of the semivariogram, $C=C_{0}+C_{1}$, the sill.

Based on the Equation 4 and following the methodology proposed by Seidel, Oliveira (2014a), it is possible to calculate the spatial correlation areas for the Cubic, Pentaspherical and Wave models. The calculation of the spatial correlation area (SCA) for the Cubic, Pentaspherical and Wave semivariogram models, respectively, are given by: 


$$
\begin{aligned}
& S C A_{\text {cubic }}=\int_{0}^{a}\left\{1-\left[\frac{C_{0}+C_{1}\left[7\left(\frac{h}{a}\right)^{2}-\frac{35}{4}\left(\frac{h}{a}\right)^{3}+\frac{7}{2}\left(\frac{h}{a}\right)^{5}-\frac{3}{4}\left(\frac{h}{a}\right)^{7}\right]}{C}\right]\right\} d h=0.365\left(\frac{C_{1}}{C_{0}+C_{1}}\right) a \\
& S C A_{\text {pentaspherical }}=\int_{0}^{a}\left\{1-\left[\frac{C_{0}+C_{1}\left[\frac{15}{8}\left(\frac{h}{a}\right)-\frac{5}{4}\left(\frac{h}{a}\right)^{3}+\frac{3}{8}\left(\frac{h}{a}\right)^{5}\right]}{C}\right]\right\} d h=0.312\left(\frac{C_{1}}{C_{0}+C_{1}}\right) a \\
& S C A_{\text {wave }}=\int_{0}^{a}\left\{1-\left[\frac{C_{0}+C_{1}\left[1-\frac{\sin \left(\pi \frac{h}{a}\right)}{\pi \frac{h}{a}}\right]}{C}\right]\right\} d h=0.589\left(\frac{C_{1}}{C_{0}+C_{1}}\right) a
\end{aligned}
$$

where $C_{0}$ is the nugget effect and $C_{1}$ is the contribution, $\mathrm{C}=C_{0}+C_{1}$ is the sill, $a$ is the range parameter, $h$ is the distance between points and $\gamma(h)$ is the theoretical model of the semivariogram.

In Equations 5, 6 and 7 we note each model has a specific constant in its respective SCA expression. This constant, inherent to each model, is the model factor (MF) that reflects the strength of the specific spatial dependence (Seidel, Oliveira, 2014a; 2014b; 2016).

From the spatial correlation areas (SCA) given in equations 5, 6 and 7, is calculated the spatial dependence index (SDI), following the methodology of Seidel, Oliveira (2014a; 2016).

After, from the calculated SDI index, its categorization and classification allow the spatial dependence interpretation as follows: weak spatial dependence; moderate spatial dependence; strong spatial dependence. For this, the methodology and the results in Seidel, Oliveira (2016) were considered.

Also, to show the applicability of the SDI index, we use real data from some articles in Environmental Sciences, Geosciences and Agricultural Sciences to calculate the index and classify the spatial dependence.

\section{Results and discussion}

The SCA is usually given in meters, which is the measurement unit of the range. Therefore, following the same suggestion of Seidel, Oliveira (2014a; 2016) to make the dimensionless 
dimension, it is necessary to multiply each of the Equations 5,6 and 7 by the term $\frac{1}{0.5 M D}$, in which $0.5 \mathrm{MD}$ corresponds to the value of half the largest distance between two sampled points. This is based on the practical recommendations of using pairs of points up to half of the largest sampling distance to construct the semivariogram (Journel, Huijbregts, 2003; Landim, 2007; Olea, 2006; Soares, 2006).

In this way, with this modification, the spatial dependence index (SDI) is constructed. The SDI index expressions for the Cubic, Pentaspherical and Wave semivariogram models are, respectively:

$$
\begin{aligned}
& S D I_{\text {cubic }}(\%)=0.365\left(\frac{C_{1}}{C_{0}+C_{1}}\right)\left(\frac{a}{0.5 M D}\right) 100 \\
& S D I_{\text {pentaspherical }}(\%)=0.312\left(\frac{C_{1}}{C_{0}+C_{1}}\right)\left(\frac{a}{0.5 M D}\right) 100 \\
& S D I_{\text {wave }}(\%)=0.589\left(\frac{C_{1}}{C_{0}+C_{1}}\right)\left(\frac{a}{0.5 M D}\right) 100
\end{aligned}
$$

where, the constants $0.365,0.312$ and 0.589 are, respectively, the MF values for the Cubic, Pentaspherical and Wave models, $C_{0}$ is the nugget effect, $C_{1}$ is the contribution, $a$ is the range, $0.5 \mathrm{MD}$ corresponds to the half of the maximum distance (MD) between the sampled points. When the ratio $\frac{a}{0.5 M D}$ result in a value greater than 1 , it must be set to 1 (truncated in 1 ) so that the SDI can assume only values between zero and 1.

The use of this index in spatial dependence evaluations applied on geospatial data can also be justified observing the semivariograms in Figure 1, because if the SPD index is calculated for both semivariograms, Figure $1 a$ and Figure $1 b$, the spatial dependence degree will be the same. However, applying the SDI index, it would capture the difference between the spatial dependence of semivariograms in Figure $1 \mathrm{a}$ and Figure $1 \mathrm{~b}$, which have different ranges. This ability to also capture the range variation is fundamental, as emphasized by Ferraz et al. (2012), the range has considerable importance in determining the limit of spatial dependence. For Lima et al. (2014), the values of the range correspond to the rays of areas considered homogeneous for each variable under study. 


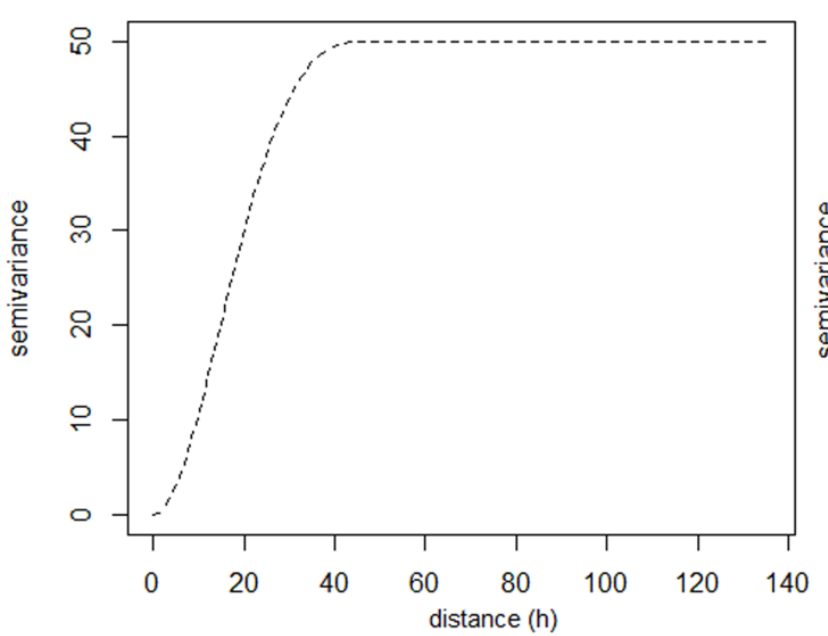

(a)

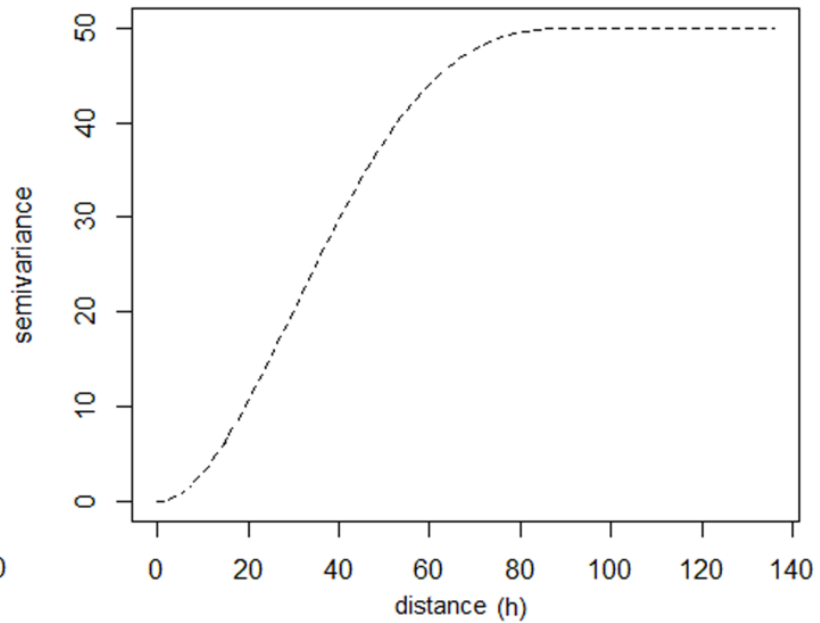

(b)

Figure 1: Cubic semivariograms (a) with zero nugget effect, contribution 50 and range 50; and (b) with zero nugget effect, contribution 50 and 100 range.

* Simulated semivariograms in geoR (Ribeiro Jr., Diggle, 2001), R (R Core Team, 2014).

The SDI index presents the following variation scale: from zero to $31.2 \%$ in the Pentaspherical model; from zero to $36.5 \%$ in the Cubic model; from zero to $58.9 \%$ in the Wave model. In Seidel, Oliveira (2014a) we note the SDI index for the Spherical, Exponential and Gaussian models ranges from zero to $37.5 \%$, zero to $31.7 \%$, and zero to $50.4 \%$, respectively. Thus, considering all the models with sill in which the index was obtained (Spherical, Exponential, Gaussian, Cubic, Pentaspherical and Wave), the SDI for the Wave model is the one with the greatest amplitude, consequently, this model has greater spatial dependence strength (higher MF). In contrast, the Pentaspherical model presents the lowest MF. Then, taking into account the six models, from the lowest to the highest MF value, the following ordered arrangement can be generated: Pentaspherical, Exponential, Cubic, Spherical, Gaussian and Wave. However, if the equivalent SDI (SDI*), proposed by Barbosa et al. (2017), for the Power semivariogram model, whose equivalent $\mathrm{MF}\left(\mathrm{MF}^{*}\right)$ ranges from 0 to $0.667\left(0<\mathrm{MF}^{*}<0.667\right)$, it is considered that the lowest value $\left(\mathrm{SDI} \mathrm{I}^{*}>0 \%\right)$ and the highest value (SDI*<66.7\%) of the SDI can be obtained for this model. But, this does not mean that one model is better than another, being only an inherent characteristic of each model, not representing fragility or less power to describe the spatial dependence behavior.

The SDI classification was based on Seidel, Oliveira (2016) matching the cuts (to categorize the spatial dependence as weak, moderate and strong) in the SDI of Spherical, Exponential and Gaussian models with the cuts in the SDI of the Cubic, Pentaspherical and Wave models. This is done because the SDI indexes have the same positive asymmetry behavior, changing only the variation scale. So, by determining the proportionality between the SDI index scales in each model, it is possible to obtain the median and third quartile values of the SDI in the Cubic, Pentaspherical and Wave models, being defined as the cuts to obtain the spatial dependence classification, as presented in Table 1. 
Table 1: Proposed spatial dependence classification based on SDI for the Cubic, Pentaspherical and Wave models.

\begin{tabular}{cccc}
\hline Cubic & Pentaspherical & Wave & $\begin{array}{c}\text { Spatial } \\
\text { Dependence }\end{array}$ \\
\hline SDI $(\%) \leq 7 \%$ & SDI $(\%) \leq 6 \%$ & SDI $(\%) \leq 11 \%$ & Weak \\
$7 \%<$ SDI $(\%) \leq 15 \%$ & $6 \%<$ SDI $(\%) \leq 12 \%$ & $11 \%<$ SDI $(\%) \leq 24 \%$ & Moderate \\
SDI $(\%)>15 \%$ & SDI $(\%)>12 \%$ & SDI $(\%)>24 \%$ & Strong \\
\hline
\end{tabular}

The procedure used by Seidel, Oliveira (2016), and replicated in this article, is based on the classification presented by Cambardella et al (1994). However, the cuts used in that work of Cambardella et al (1994) (25\% and 75\%) correspond to cuts in the first and third quartile of the index, respectively, because theoretically the SPD (or NE) behaves symmetrically.

According to Seidel, Oliveira (2016), because of the difference in the index distributions, there is a discrepancy between the classification of Cambardella et al. (1994) (for the SPD) and SDI classification.

The SDI has the potential to evaluate spatial dependence from the semivariograms adjustment, which may be the only index used for such evaluation (Pazini et al., 2015; Buttow et al., 2017; Pelissari et al., 2017), or be used in conjunction with other measures of spatial dependence (Oldoni, Bassoi, 2016).

In order to verify the applicability of the SDI index, real data obtained from some papers in Environmental Sciences, Geosciences and Agricultural Sciences areas were considered. In these papers, the Cubic model (Chand et al., 2005; Olea, 2006), Pentaspherical model (Cruz-Cárdenas et al., 2013; Oliveira et al., 2013) and Wave model (Carvalho et al., 2009; Siqueira et al., 2012; Lima et al., 2014; Pasini et al., 2014) were adjusted to the semivariogram to estimate the spatial dependence. The results are shown in Table 2.

Table 2: Estimated range values $(a)$, nugget effect $\left(C_{0}\right)$, contribution $\left(C_{1}\right)$, spatial dependence degree (SPD), spatial dependence index (SDI), SPD and SDI classifications in real data obtained from some articles in the literature.

\begin{tabular}{|c|c|c|c|c|c|c|c|}
\hline Attribute & $\boldsymbol{a}(\mathrm{m})$ & $\mathrm{C}_{0}$ & $\mathrm{C}_{1}$ & SPD & SDI@ & Classi. SPD & Classi. SDI \\
\hline $\begin{array}{c}\text { Bouguer } \\
\text { anomaly*1 }\end{array}$ & $20.52 \times 10^{3}$ & 0.03 & 0.99 & 97.06 & 22.88 & STRONG & STRONG \\
\hline $\begin{array}{l}\text { Recharge } \\
\text { values*\| }\end{array}$ & 1.90 & 0.60 & 2.10 & 77.77 & 4.61 & STRONG & WEAK \\
\hline $\begin{array}{c}\text { Species } \\
\text { richness**III }\end{array}$ & $2.46^{\&}$ & 0,00 & 0.94 & 100.00 & 4.74 & STRONG & WEAK \\
\hline $\begin{array}{l}\text { Sand }(0.0- \\
0.2 \mathrm{~m})^{* *} \mathrm{IV}\end{array}$ & 470.00 & $3.1 \times 10^{3}$ & $18.0 \times 10^{3}$ & 85.31 & 15.64 & STRONG & STRONG \\
\hline $\begin{array}{l}\text { Silt }(0.0- \\
0.2 \mathrm{~m})^{* *} \mathrm{IV}\end{array}$ & 340.00 & $1.3 \times 10^{3}$ & $6.0 \times 10^{3}$ & 82.19 & 10.90 & STRONG & MODERATE \\
\hline $\begin{array}{l}\text { Sand }(0.2- \\
0.4 \mathrm{~m})^{* * 1 \mathrm{IV}}\end{array}$ & 460.00 & 500,00 & $21.6 \times 10^{3}$ & 97.74 & 17.53 & STRONG & STRONG \\
\hline $\begin{array}{l}\text { Silt }(0.2- \\
0.4 \mathrm{~m})^{* *} \mathrm{IV}\end{array}$ & 340.00 & $1.3 \times 10^{3}$ & $6.0 \times 10^{3}$ & 82.19 & 10.90 & STRONG & MODERATE \\
\hline
\end{tabular}




\begin{tabular}{|c|c|c|c|c|c|c|c|}
\hline $\begin{array}{c}\text { Average } \\
\text { rainfall } * * * V\end{array}$ & $15.23 \times 10^{3}$ & $16.04 \times 10^{3}$ & $32.3 \times 10^{3}$ & 66.81 & 2.40 & MODERATE & WEAK \\
\hline $\begin{array}{c}\text { Air } \\
\text { temperature } * * * V I\end{array}$ & $8.23 \times 10^{3}$ & 0.51 & 0.84 & 62.22 & 0.76 & MODERATE & WEAK \\
\hline $\mathrm{Ca} * * * \mathrm{VII}$ & 706.50 & 1.62 & 2.12 & 56.68 & 8.42 & MODERATE & WEAK \\
\hline $\begin{array}{l}\text { Number of fig } \\
\text { flies****VII }\end{array}$ & 98.30 & 0.00 & 11.29 & 100.00 & 58.90 & STRONG & STRONG \\
\hline
\end{tabular}

Based on the SPD index, the Table 2 shows that most of the attributes were classified as having strong spatial dependence while the SDI index, which also considers the range effect, has more weak spatial dependence classifications. In this aspect, from 8 strong classifications originated by the SPD, only 4 of them were maintained using the SDI. From 3 moderated classifications by SPD, all of them changed to weak dependence classification when considering SDI. The reason for these disagreements between the classifications generated by these two indexes is not only the difference of methodologies but fundamentally the fact that the SDI contemplates more semivariogram aspects to describe the spatial variability.

The behavior of the first and third attributes of Table 2 exemplifies the differences between the classifications of these two indexes. By the SPD, the dependence is strong in both cases, because of the nugget effect values (0.03 and 0.00 ) and the contribution values (0.99 and 0.94). However, when using the SDI, the spatial dependences of these two attributes are considered distinct, the first remains classified as strong and the second changes to a weak spatial dependence. This situation is explained by the fact that the range values of these two attributes are different $\left(20.52 \times 10^{3}\right.$ and 2.46$)$ and this is captured by the SDI index.

The presentation of the attributes in Table 2 is intended only to illustrate the application of the SDI index and the interpretation of its classification in relation to the spatial dependence degree in field data. However, it is important to consider the range value in the spatial dependence evaluation. This information corroborates with Seidel, Oliveira (2014a), who comment that it is necessary to consider all aspects of the semivariogram to construct spatial dependence measures, making the spatial characterization more complete and reliable.

\section{Conclusion}

Based on the spatial correlation areas (SCA) concept, we present the spatial dependence index (SDI) for the Cubic, Pentaspherical and Wave semivariogram models.

In addition, from a theoretical distribution of values for the index, we propose a spatial dependence classification categorized as weak, moderate and strong spatial dependence. 


\section{REFERENCES}

Ávila, L. F., Mello, C. D., Silva, A. D. 2010. Continuidade e distribuição espacial da umidade do solo em bacia hidrográfica da Serra da Mantiqueira. Revista Brasileira de Engenharia Agrícola e Ambiental, 14(12), pp.1257-1266. doi: 10.1590/S1415-43662010001200002

Barbosa, I. C., Appel Neto, E., Seidel, E. J., Oliveira, M. S. 2017. Proposal of the spatial dependence evaluation from the power semivariogram model. Boletim de Ciências Geodésicas, 23(3), pp.461475. doi: 10.1590/S1982-21702017000300031

Biondi, F., Myers, D. E., Avery, C. C. 1994. Geostatistically modeling stem size and increment in an old-growth forest. Canadian Journal of Forest Research, 24(7), pp.1354-1368. doi: 10.1139/x94176

Buttow, G. T., Pazini, J. B., Seidel, E. J., Silva, F. F., Grutzmacher, A. D., Martins, J. F. S. 2017. Relationship between the occurrence of the rice water weevil and water depth in flooded rice crop. Pesquisa Agropecuária Brasileira, 52(7), pp.557-560. doi: 10.1590/s0100$204 \times 2017000700010$

Cambardella, C. A., Moorman, T. B., Parkin, T. B., Karlen, D. L., Novak, J. M., Turco, R. F., Konopka, A. E. 1994. Field-scale variability of soil properties in central lowa soils. Soil science society of America journal, 58(5), pp.1501-1511. doi: 10.2136/sssaj1994.03615995005800050033x

Carvalho, J. D., Vieira, S. R., Grego, C. R. 2009. Comparação de métodos para ajuste de modelos de semivariograma da precipitação pluvial anual. Revista Brasileira de Engenharia Agrícola e Ambiental, 13(4), pp.443-448. doi: 10.1590/S1415-43662009000400011

Chand, R., Hodlur, G. K., Prakash, M. R., Mondal, N. C., Singh, V. S. 2005. Reliable natural recharge estimates in granitic terrain. Current science, 88(5), pp.821-824.

Cruz-Cárdenas, G., Villaseñor, J. L., López-Mata, L., Ortiz, E. 2013. Distribución espacial de la riqueza de especies de plantas vasculares en México. Revista mexicana de biodiversidad, 84(4), pp.1189-1199. doi: 10.7550/rmb.31811

Faraco, M. A., Uribe-Opazo, M. A., Silva, E. A. A. D., Johann, J. A., Borssoi, J. A. 2008. Seleção de modelos de variabilidade espacial para elaboração de mapas temáticos de atributos físicos do solo e produtividade da soja. Revista Brasileira de Ciência do Solo, 32(2), pp.463-476. doi: 10.1590/S0100-06832008000200001

Ferraz, G., Silva, F. D., Carvalho, L. C. C., Alves, M. D. C., Franco, B. C. 2012. Variabilidade espacial e temporal do fósforo, potássio e da produtividade de uma lavoura cafeeira. Engenharia Agrícola, 32(1), pp.140-150. doi: 10.1590/S0100-69162012000100015

Journel, A. G.; Huijbregts, C. J. 2003. Mining geostatistics. Caldwell: Blackburn Press.

Landim, P. M. B. 2006. Sobre geoestatística e mapas. Terrae Didatica, 2(1), pp.19-33. doi: 10.20396/td.v2i1.8637463

Lima, G. C., Silva, M. L., de Oliveira, M. S., Curi, N., Da Silva, M. A., Oliveira, A. H. 2014. Variabilidade de atributos do solo sob pastagens e mata atlântica na escala de microbacia hidrográfica. Revista Brasileira de Engenharia Agricola e Ambiental, 18(5), pp.517-526. doi: 10.1590/S141543662014000500008 
Oldoni, H., Bassoi, L. H. 2016. Delineation of irrigation management zones in a Quartzipsamment of the Brazilian semiarid region. Pesquisa Agropecuária Brasileira, 51(9), pp.1283-1294. doi: 10.1590/s0100-204×2016000900028

Olea, R. A. 2006. A six-step practical approach to semivariogram modeling. Stochastic Environmental Research and Risk Assessment, 20(5), pp.307-318. doi: 10.1007/s00477-005-00261

Oliveira, D. P. D., Ferreira, T. O., Romero, R. E., Farias, P. R. S., Costa, M. C. G. 2013. Microrrelevo e a distribuição de frações granulométricas em Cambissolos de origem calcária. Revista Ciência Agronômica, 44(4), pp.676-684. doi: 10.1590/S1806-66902013000400003

Pasini, M. P. B., Dal'Col Lúcio, A., Cargnelutti Filho, A. 2014. Semivariogram models for estimating fig fly population density throughout the year. Pesquisa Agropecuária Brasileira, 49(7), pp.493505. doi: 10.1590/S0100-204X2014000700001

Pazini, J. D. B., Botta, R. A., Seidel, E. J., Silva, F. F. D., Martins, J. F. D. S., Barrigossi, J. A. F., Rübenich, R. 2015. Geostatistics applied to the study of the spatial distribution of Tibraca limbativentris in flooded rice fields. Ciência Rural, 45(6), pp.1006-1012. doi: 10.1590/0103-8478cr20140841

Pelissari, A. L., Roveda, M., Caldeira, S. F., Sanquetta, C. R., Dalla Corte, A. P., Rodrigues, C. K. 2017. Geostatistical modeling of timber volume spatial variability for Tectona grandis L. F. precision forestry. Cerne, 23(1), pp.115-122. doi: 10.1590/01047760201723012291

R Core Team. 2014. R: A language and environment for statistical computing. R Foundation for Statistical Computing, Vienna, Austria.

Ribeiro Jr, P. J., Diggle, P. J. 2001. geoR: a package for geostatistical analysis. $R$ news, 1(2), pp.1418.

Seidel, E. J., Oliveira, M. S. D. 2014a. Novo índice geoestatístico para a mensuração da dependência espacial. Revista Brasileira de Ciência do Solo, 38(3), pp.699-705. doi: 10.1590/S010006832014000300002

Seidel, E. J., Oliveira, M. S. D. 2014b. Proposta de um teste de hipótese para a existência de dependência espacial em dados geoestatísticos. Boletim de Ciências Geodésicas, 20(4), pp.750764. doi: 10.1590/S1982-21702014000400043

Seidel, E. J., Oliveira, M. S. D. 2016. A Classification for a Geostatistical Index of Spatial Dependence. Revista Brasileira de Ciência do Solo, 40, e0160007. doi: 10.1590/18069657rbcs20160007

Siqueira, G. M., Bezerra, J. M., Vieira, S. R., de Camargo, M. B. P. 2012. Zoneamento de Parâmetros Climáticos no Estado de São Paulo (Brasil) Utilizando Técnicas de Geoestatística. Revista Brasileira de Geografia Física, 5(3), pp.612-629. doi: 10.26848/rbgf.v5i3.232874

Soares, A. 2006. Geoestatística para as Ciências da Terra e do Ambiente. 2 ed. Lisboa: IST Press.

Trangmar, B. B., Yost, R. S., Uehara, G. 1985. Application of geostatistics to spatial studies of soil properties. Advances in agronomy, 38, pp.45-94. doi: 10.1016/S0065-2113(08)60673-2

Yamamoto, J. K., Mao, X. M., Koike, K., Crosta, A. P., Landim, P. M. B., Hu, H. Z., ... \& Yao, L. Q. (2012). Mapping an uncertainty zone between interpolated types of a categorical variable. Computers \& Geosciences, 40, pp.146-152. doi: 10.1016/j.cageo.2011.09.005 